\title{
Population Growth and Unemployment in Nigeria
}

\author{
Babatunde Afolabi $\mathrm{PhD}^{1} \quad$ Awopetu, Olayinka Bobola ${ }^{2}$ \\ 1.Department of Banking and Finance, Afe Babalola University, Ado Ekiti. (ABUAD) Nigeria \\ 2.Department of Economics, Afe Babalola University, Ado Ekiti. (ABUAD) Nigeria
}

\begin{abstract}
The Nigerian economy has been seriously bedeviled by a myriad of economic malaise that has explained the slow pace of its growth rate and a severe decline in development. It is in view of the above that the study critically examined the relationship between population growth and unemployment in Nigeria. The paper employed data from secondary sources which covered the period of 1991-2016, sourced from the World Bank data base. The method of analysis was the Johansen Cointegration and Error correction model. ADF unit root test was used to establish the order of integration of the variables. Granger causality test was used to examine the direction of causality among the variables. A positive relationship was found to exist between population growth and unemployment. The result of the regression analysis shows that population plays a major role in the increased level of unemployment in Nigeria. The findings showed that population growth has a strong impact on unemployment in Nigeria. This means that a rise in population growth leads to a rise in unemployment. The study concluded that to combat the acute unemployment in the country, the Government should ensure there is job creation especially in the agricultural and manufacturing sectors. Private sectors employers should be given subsidies so as to encourage them to employ more people.
\end{abstract}

Keywords: Population growth, Unemployment, Corruption, Rural urban migration.

JEL Classification: E24, J62, J11

DOI: $10.7176 / \mathrm{JESD} / 11-2-10$

Publication date: January $31^{\text {st }} 2020$

\subsection{Introduction}

The Nigerian Economy is typified by high level of population growth, as it is the most populous nation in Africa and the $8^{\text {th }}$ in the world with an estimated figure of about 170 million people based on the facts released by the National Population Commission in the year 2012. Also, Nigeria admits to be the largest economy in Africa with the GDP standing at 13,526.25 and 14,475.38 billion in the year 2013 and 2014 respectively. Despite all these, Nigeria still faces several developmental, economic and political challenges such as unemployment, poverty, corruption, population explosion, income inequality and political instability.

Nigeria has been experiencing population growth for the past 50 years as a result of high natality rates which increases the population geometrically over time.

Unemployment occurs as a result of the insufficiency of jobs to commensurate with the rapid population growth, even those who are already employed are afraid of being rendered unemployed due to the insecurity of the job, economic recession and retrenchment of workers. (Akiri et al. 2016).

The rate of unemployment in Nigeria is growing at an alarming rate amidst growing population rate and these posses a devastating effect on the Nigerian Economy. Recently, the public violence, insurgency, high crime rate e.t.c experienced by the Nigerian Economy are assumed to be products of unemployment in a growing population. Moreover, it was argued that the greater percentages of these criminals are unemployed, potential labour force. Nigeria's big concern however is how to produce sufficient employment opportunity so as to absorb the Country's growing pool of labour.

Unemployment have been the major problem bothering the LDCs especially Nigeria and it is an hindrance to the attainment of sustainable development .This in fact poses a serious concern to the citizens, government, economists and other analysts in the economy and has been tagged as a barricade to social and economic advancement especially in developing nations, including Nigeria.

The unemployment situation of youths has led to socio-economic, moral and political vices such as armed robbery, thuggery, corruption, depression, rural urban migration, wastage and under utilization of human resources, high dependency ratio, etc. Unemployment situation has brought the presence of poverty in Nigeria. Successive government has employed various strategies to curb unemployment challenges, but good results have not been achieved so far.

Nigeria population requires urgent attention, regulation and control due to its excessive growth rate. This population situation of Nigeria needs to be discussed to expose many population related factors to the consciousness of the people. Nigeria for instance is suffering from high rate of poverty and unemployment. Also, there is a mass rural urban migration which creates social vices. This happens because the available industries are unable to employ all the people in the labour market.

The aim of this paper is to study the growth rate of population and employment trends in LDCs. It also aims 
at reviewing the profile of Nigeria population and to determine the various factors affecting population in Nigeria.

\subsection{Literature Review}

\subsection{Theoretical Literature Review}

The nature of the relationship between population growth and economic growth has caused the attraction of a large number of the world's most influential thinkers that most of them have started propounding theories to explain the relationship. Rev. Thomas Malthus, over 2 centuries ago, in his Essay on the "principles of population" suggested the threshold level at which population increase was bound to stop because the resources which increases at an arithmetic rate would be insufficient to support population growth which increases at a geometric rate. If nothing is done to check the growth rate of population, it would outshine the means of subsistence.

Employment problem, which consists of open unemployment, underemployment, low wage employment, social exclusion etc, is noticeable in almost every market economy today. These are more serious in the Less Developed Countries than in the Developed Countries of the world. Richard Curtain, a Professional Associate of the National Institute for Governance, Australia was of the opinion that "unemployment is really high among the youths and is aggravated by the mismatch between vocational training and the employment needs of the economy.

Youth unemployment is a problem that has been evident in Nigeria. It has been discovered in Nigeria that Vendors, bike riders and hawkers, who are scattered on the street with an average level of education would have secured employment or display their personal skills and resources if they had a conducive environment and structure that encourage such. Most of the early writers on population growth were seriously concerned with the need to balance population with resources.

Godday Odidi (Quoted from his article "Tackling youth unemployment: The way forward) defined unemployment as a state of people living in absolute joblessness which ranges between the ages of 20-40 while underemployment is a situation in which people who are gainfully employed but not financially rewarding to authenticate their qualifications.

According to the international Labour Organization, unemployed individuals are members of the Country's active population who are able, willing, and available, seeking for job bit cannot find any work, and also cannot find the type of job of their expertise or training. According to Statistics report from the Bureau of statistics, it was reported that Nigeria has $60 \%$ of its population to be youths, i.e. an estimate of 80 million people (P.S.O. Uddin and Uddin. 2013). It was also reported that 64 million of the youths are unemployed, while about 1.6 million of the people are under- employed.

Okafor (2004:84), argued that population is a critical factor in the development plans of any civilized society. For planning to be effective for the less developed countries development, it is essential to have a count of the population (i.e. census). This will enhance the government to know how many people to whom they should distribute the amenities and social services. According to Udabah (2002:59), Population is a central problem of economic development. If a country's population increases as fast as national income, then per capital income will not increase. A rapid population growth leads to low standard of living of the people. Much of the problems of developing countries like Nigeria is population growth as they have made appreciable gains in income but most of the gains have been eaten up by the increasing population.

(Akiri et al.2016) argued that Unemployment occurs as a result of the insufficiency of jobs to commensurate with the rapid population growth, even those who are already employed are afraid of being rendered unemployed due to the insecurity of the job, economic recession and retrenchment of workers.

The early Roman Christians and Islamic writers were largely in favour of population growth without showing concern for the need to balance the number of people with available resources.

\subsection{Empirical Review}

Various researches have been used to explain the various causes of unemployment and its impact on the Countries and regions. Botero et al, (2003) in his study examined the economic impact of employment, social security, collective bargaining and industrial laws for 85 Countries. It was discovered that wealthy nations do not regulate labour as often as the poor ones, but instead they offer more social securities. Furthermore, they opined that severe regulation of labour is harmful to labour force participation and creates higher unemployment. Cesar and Chong (2003) believed that economic growth is affected poorly by wider labour codes. Therefore, they argued that economic growth could be encouraged by less labour regulations, particularly in less developed countries. Petrin and Sivadasan (2006) examined the impact of employment protection legislation (EPL) on manufacturing firms in Chile from 1979-1996 using plant level production data. Their result showed little evidence of a negative effect of EPL on demand for labour. They discovered that EPL brought significant costs to the economy.

According to Micco and Pages (2006), "employment protection legislation (EPL) reduced job flows, especially in more unstable sectors. Though, they concluded that labour regulations do not really affect productivity of labour. This was opposed by Cingano et al (2010), in his research. He discovered that harmful effects of EPL on labour productivity especially in sector with high rate of labour reallocation. 
Griffith et al. (2006) in their research analyzed the effect of product market competition on wages and unemployment, and how it depends on labour market institutions. They applied varying alterations in regulations across the Organization for Economic Co-operation and Development (OECD) countries over 1980s and 1990s to discover the effects of competition. They reviewed that increase in the product market competition decreases unemployment, and that it does so more in nations with labour market institutions that raises worker's bargaining power.

Nickell et al. (2002) reviewed OECD from 1961-1995 and suggested that changes in labour international journal of development and sustainability market institutions accounted for around 55\% of the increase in European unemployment from the 1960s to the first half of 1990s. Baccaro and Rei (2007), in their research which investigated the impact of institutions and regulations on unemployment in OECD fell short of to realize any cogent proof of either direct or indirect impact of labour market institution on unemployment. Schindler (2009) argued that both labour market reforms structure and sequence are vital for labour market outcomes and the related costs of reforms. Tvron (2015) analyzed in his research two major institutional factors that significantly affect labour market performance and these are: tax wedge on labour activities and active labour market policies. It demonstrates that a higher tax has direct relationship with unemployment, but effective labour market policies have the propensity to counterbalance the negative impact of high taxation.

Fabio and Scharler (2011) examined labour market institutions and macroeconomic volatility in a panel of OECD countries with an empirical examination on how labour market institutions impact business cycle volatility in a sample of 20 OECD countries. He discovered in his findings that nations typified by high union density are most likely to go through more volatile changes in output, while the level of organization of the wage bargaining system as well as strictness of employment protection legislation seems to play a limited role for output volatility.

\subsection{Methodology Model Specification}

The channel, through which, population affect unemployment is through the level of economic activities in the country. If economic activities increase with the pace of population, the increased population will be absorbed, and unemployment will not be a concern. Hence, population increase becomes a problem, when there is no corresponding level of activities to absorb the population. Based on this, the model below is specified.

TOTUEM $_{t}=f\left(\right.$ POPULOT $_{t}$, DOMEMA $_{t}$, FDIFLO $_{t}$, EXCHAN $\left._{t}\right)$

Where TOTUEM is total unemployment rate, which was measured using the ratio of the unemployed to labour force, POPULOT is the log of total population in the country, DOMEMA is the size of domestic market or activities. It was proxied with log of gross domestic product, FDIFLO is flow of FDI, EXCHAN is the log of exchange rate. The model is further presented empirically in equation 3.2.

Data Type and Source

$$
\text { TOTUEM }_{t}=\theta_{0}+\theta_{1} \text { POPULOT }_{t}+\theta_{2} \text { DOMEMA }_{t}+\theta_{3} \text { FDIFLO }_{t}+\theta_{4} \text { EXCHAN }_{t}+\varepsilon_{t}
$$

The data used for the model are time-series data. The data spans from 1991 to 2016.

\section{Analytical Techniques}

The variables used in the analysis were first examined for the status of unit root in them. This was done using ADF unit root test. Johansen co-integration procedure was used for the long run relationship, while error correction model was used to capture the short run results of the analysis. Granger causality test was used to identify the direction of causalities among the variables.

\subsection{Discussion of Results}

\subsection{Testing for presence of Unit Roots in the Variables}

Table 4.1 shows the results of unit root in the variables when they were tested at level and after they were differenced once. When the tests were conducted on the variables before they were differenced, the probability of T-statistics is 0.2 for total population that of total unemployment is $0.3,0.1$ for FDI inflow, 0.9 for domestic market, while it is 0.6 for exchange rate. They are all greater than 0.05 . Similarly, the statistics for the $\mathrm{T}$ test are lower than the critical values at $1 \%$ and $5 \%$ for all the variables. This suggests that they contain unit roots.

On the other hand, the probability value of the tests on the variables after differencing them once is less than $5 \%$. It is 0.0047 for total population, 0.0011 for total unemployment, 0.0002 for FDI inflow, 0.0102 for domestic market, while it is 0.0011 for exchange rate. In other words, all the variables, apart from domestic markets, are significant at $1 \%$, while domestic market is significant at $5 \%$. This therefore brings the conclusion that differencing the variables once, helps removes the unit root problem. 
Table 4.1: The Results of the UNIT Root Test using ADF Unit Root Test

\begin{tabular}{|l|c|l|l|l|l|l|}
\hline \multicolumn{8}{|c|}{ ADF AT LEVEL } \\
\hline & t-Statistic & Prob. & $1 \%$ level & $5 \%$ level & $10 \%$ level & \\
\hline POPULOT & -2.667176 & 0.2583 & -3.724070 & -2.986225 & -2.632604 & Contains Unit Root \\
\hline TOTUEM & -1.866399 & 0.3417 & -3.724070 & -2.986225 & -2.632604 & Contains Unit Root \\
\hline FDIFLO & -2.554044 & 0.1156 & -3.724070 & -2.986225 & -2.632604 & Contains Unit Root \\
\hline DOMEMA & -0.325239 & 0.9749 & -3.724070 & -2.986225 & -2.632604 & Contains Unit Root \\
\hline EXCHAN & -1.259463 & 0.6317 & -3.724070 & -2.986225 & -2.632604 & Contains Unit Root \\
\hline \multicolumn{8}{|c|}{ ADF AFTER FIRST DIFFERENCE } \\
\hline POPULOT & $-4.139599 * *$ & 0.0047 & -3.788030 & -3.012363 & -2.646119 & No Unit Root \\
\hline TOTUEM & $-4.679880 * *$ & 0.0011 & -3.737853 & -2.991878 & -2.635542 & No Unit Root \\
\hline FDIFLO & $-5.423802 * * *$ & 0.0002 & -3.737853 & -2.991878 & -2.635542 & No Unit Root \\
\hline DOMEMA & $-3.731017 * *$ & 0.0102 & -3.737853 & -2.991878 & -2.635542 & No Unit Root \\
\hline EXCHAN & $-4.676721 * * *$ & 0.0011 & -3.737853 & -2.991878 & -2.635542 & No Unit Root \\
\hline
\end{tabular}

$* * *$ indicates significance at $1 \%, * *$ indicates significance at $5 \%$,

Sources: Author Computation, 2019.

\subsection{Testing For the Lag Length Criteria}

Table 4.2 shows that Akaike information criterion indicates optimal lag of 2, Hannan-Quinn information criterion indicate optimal lag of two, Final prediction error indicate optimal lag length of two, but Schwarz information criterion indicate optimal lag of one. Since most of the lag selection criterion indicate optimal lag of 2, the optimal lag for the analysis was chosen to be two.

Table 4.2: Lag Length Selection

\begin{tabular}{|c|c|c|c|c|c|c|}
\hline Lag & Log L & LR & FPE & AIC & SC & HQ \\
\hline 0 & -29.11887 & NA & $1.18 \mathrm{e}-05$ & 2.843239 & 3.088667 & 2.908351 \\
\hline 1 & 192.2451 & 332.0460 & $9.76 \mathrm{e}-13$ & -13.52043 & $-12.04786^{*}$ & -13.12975 \\
\hline 2 & 227.8589 & $38.58159^{*}$ & $5.52 \mathrm{e}-13^{*}$ & $-14.40491^{*}$ & -11.70520 & $-13.68867^{*}$ \\
\hline
\end{tabular}

* indicates lag order selected by the criterion

LR: sequential modified LR test statistic (each test at 5\% level)

FPE: Final prediction error

AIC: Akaike information criterion

SC: Schwarz information criterion

HQ: Hannan-Quinn information criterion

Sources: Author Computation, 2019.

\subsection{Testing for a Long Run Relationship among the Variables}

Table 4.3 shows the result of both the Trace test, in the upper segment, and that of the Max-eigen value Test, in the lower segment. For the Trace test, the hypothesis of no c-integrating equation can be rejected up till fourth cointegrating vector. This therefore indicates that there at least four co-integrating vectors in the model. Similarly, in the lower segment, the hypothesis of no co-integrating equation can be rejected until the third co-integrating vector. This indicates at least three co-integrating vectors in the model. This therefore brings the conclusion that a long run relationship exists among the variables in the model. 
Table 4.3: Result of Johansen Test of Co-integration

\begin{tabular}{|c|c|c|c|c|}
\hline \multicolumn{5}{|c|}{ Results of the Trace Test } \\
\hline Hypothesized & & Trace & 0.05 & \\
\hline No. of CE(s) & Eigenvalue & Statistic & Critical Value & Prob.** \\
\hline None $*$ & 0.971508 & 204.8797 & 88.80380 & 0.0000 \\
\hline$\mu \leq 1 *$ & 0.930039 & 123.0431 & 63.87610 & 0.0000 \\
\hline$\mu \leq 2 *$ & 0.781315 & 61.86717 & 42.91525 & 0.0002 \\
\hline$\mu \leq 3 *$ & 0.499641 & 26.90434 & 25.87211 & 0.0371 \\
\hline$\mu \leq 4$ & 0.379559 & 10.97848 & 12.51798 & 0.0892 \\
\hline \multicolumn{5}{|c|}{ Trace test indicates 4 co-integrating eqn(s) at the 0.05 level } \\
\hline \multicolumn{5}{|c|}{ Results of the Max-eigenvalue Test } \\
\hline Hypothesized & & Max-Eigen & $\mathbf{0 . 0 5}$ & \\
\hline No. of CE(s) & Eigenvalue & Statistic & Critical Value & Prob.** \\
\hline None * & 0.971508 & 81.83663 & 38.33101 & 0.0000 \\
\hline$\mu \leq 1 *$ & 0.930039 & 61.17592 & 32.11832 & 0.0000 \\
\hline$\mu \leq 2 *$ & 0.781315 & 34.96283 & 25.82321 & 0.0024 \\
\hline$\mu \leq 3 *$ & 0.499641 & 15.92586 & 19.38704 & 0.1484 \\
\hline$\mu \leq 4$ & 0.379559 & 10.97848 & 12.51798 & 0.0892 \\
\hline
\end{tabular}

Sources: Author Computation, 2019.

\subsection{Explaining the Results of the Long Run Coefficients}

Given the results of the co-integrating relationship, the effects of population on unemployment can be separated into both long run and short run effects. The unrestricted coefficients of the co-integration results indicate the long run effects of population and other variables on unemployment, while the short run effects is captured by the error correction model. The result of the long run effects is presented in Table 4.4, while the fitted regression line is presented in equation 1 .

The result indicates population is strongly significant, at $1 \%$, in affecting unemployment in the long run. A positive effect exists from population to unemployment in the long run. In order words, the marginal effect of increase in population on unemployment rate in the long run is positive. Given that the model is a linear-log model, the marginal effect is $4.74 \%$. A $1 \%$ increase in population is associated with $4.74 \%$ increase in unemployment. The marginal effect is very large at $4.74 \%$. This implies that the high rate of unemployment rate in Nigeria has much to do with the high rate of population in the country.

A geometric increase in population without its associated increase in economic activities will transform to a geometric increase in unemployment rate in the country. Given the high birth rate in the country, and polygamous nature of family structure, especially in the northern part of the country, the population of the country continues to increase. More importantly, the problem of border control which makes it easy to enter the country without restrains, especially in the northern parts of the country, and thus increase the immigrant population of the country, all contribute to the rising problem of unemployment in the country. It therefore means that controlling the population rate in the country is an important way of controlling unemployment rate in the country.

Similarly, inflow of FDI into the country has a negative influence on unemployment rate in the country. The result $\mathrm{s}$ is also significant at $1 \%$. A $1 \%$ increase in FDI inflows into the country decreases the burden of unemployment by $0.0052 \%$. The marginal effect is very low, though it is positive. This implies that much inflow of FDI is still required to achieve the desired effects of FDI inflow on unemployment in the country.

The effect of domestic market on unemployment is also negative. This indicates that as the domestic market becomes large, unemployment rate decreases. In other words, a $1 \%$ increase in economic activities decreases the rate of unemployment by $0.11 \%$. However, the effect of exchange rate depreciation is positive on the rate of unemployment. An increase in the rate of exchange rate depreciation by $1 \%$ increases the rate of unemployment by $0.0097 \%$. As exchange rate depreciates, imports become expensive because of the country's dependence on imports. Inflation is imported into the country. This affects the level of investment in the country negatively. The resultant effect is increase in unemployment rate. 
Table 4.4: Unrestricted Long Run Coefficients

\begin{tabular}{|l|l|l|l|}
\hline Variables & Coefficients & Standard Error & T-statistics \\
\hline TOTUEM & 1.000000 & & \\
\hline POPULOT & -474.9059 & $52.7715)$ & -8.99928 \\
\hline FDIFLO & 0.521323 & 0.04184 & 12.4607 \\
\hline DOMEMA & 11.22166 & 0.63629 & 17.6362 \\
\hline EXCHAN & -0.975641 & 0.11109 & -8.78214 \\
\hline
\end{tabular}

Sources: Author Computation, 2019.

\subsection{The Regression Line}

TOTUEM $_{t}=8369.386+474.9059$ POPULOT $_{t}-0.521323$ FDIFLO $_{t}-11.22166$ DOMEMA $_{t}+$ $0.97564 \mathrm{EXCHAN}_{t}$

\subsection{Interpreting the Results of the Short Run Coefficients}

The short run effect is captured by specifying the error correction model. The results, which is presented in Table 4.5 , shows that population increase, lagged by one period, and rise in unemployment move in the same direction in the short run. In other words, immediate past year population increases the present unemployment rate. A $1 \%$ increase in the population of one previous period, a year, increases present rate of unemployment by $206 \%$. This shows that population increase has more influence on unemployment in the short run than in the long run. The result of the second period lag is not consistent with expected results.

Also, the effect of FDI in the short run is also positive in influencing unemployment. This is also no consistent with the expected results. However, an explanation for this may be because of the sector that FDI flows to in the country. It is generally argued that FDI flows basically to the oil sector. The development of the oil sector, at the expense of other sectors leads to what is referred to as Dutch Disease. This may impact on unemployment in the country negatively, at least in the short run. The same explanation can be given with respect to the effect of domestic activities on unemployment in the short run. As the economic activities increase in some sectors of the economy such as oil sector, other sectors of the economy may suffer some neglect, a good example of Nigerian situations. This neglected tends to affect employment activities in other sector, and thus tend to increase unemployment burden on the economy.

The error correction term is negative, and consistent with the expected rested sign, and it is significant at $1 \%$. Overall, the variables used in the model could predict about $77 \%$ of the behavior of unemployment rate in the country. Also, the overall significance of the variables is significant at $5 \%$, while DW does not show any fear of correlation among the errors of different periods. The diagnostics tests of the residuals show no problem associated with the residuals.

Table 4.5: Results of the Short Run Coefficients

\begin{tabular}{|c|c|c|c|c|}
\hline Variables & Coefficient & Std. Error & t-Statistic & Prob. \\
\hline ECTERM & $-1.611808^{* *}$ & 0.553539 & -2.911822 & 0.0141 \\
\hline TOTUEM (-1) & 0.567256 & 0.364014 & 1.558336 & 0.1474 \\
\hline TOTUEM (-2) & -0.235435 & 0.222190 & -1.059610 & 0.3120 \\
\hline DOMEMA(-1) & $8.705296^{*}$ & 4.277718 & 2.035033 & 0.0667 \\
\hline DOMEMA(-2) & $7.876505 * *$ & 3.418752 & 2.303913 & 0.0417 \\
\hline FDIFLO (-1) & 0.310324 & 0.174772 & 1.775596 & 0.1034 \\
\hline FDIFLO (-2) & $0.429853 * * *$ & 0.111481 & 3.855835 & 0.0027 \\
\hline EXCHAN(-1) & -0.643621 & 0.802668 & -0.801852 & 0.4396 \\
\hline EXCHAN(-2) & -0.453797 & 0.589047 & -0.770393 & 0.4573 \\
\hline POPULOT (-1) & $20691.43 * * *$ & 6361.712 & 3.252495 & 0.0077 \\
\hline POPULOT (-2) & -13215.81 & 3850.342 & -3.432373 & 0.0056 \\
\hline Constant & $-194.0706 * *$ & 68.54932 & -2.831109 & 0.0163 \\
\hline R-squared & 0.776029 & \multicolumn{2}{|c|}{ Durbin-Watson stat } & 1.972799 \\
\hline F-statistic & $3.464859 * * 1$ & Prob(F-statistic) & & 0.025222 \\
\hline \multicolumn{5}{|c|}{ Diagnostics } \\
\hline \multicolumn{5}{|c|}{ Breusch-Godfrey Serial Correlation LM Test: } \\
\hline F-statistic & 1.723604 & Prob. F $(2,9)$ & & 0.2324 \\
\hline \multicolumn{5}{|c|}{ Heteroskedasticity Test: Breusch-Pagan-Godfrey } \\
\hline F-statistic & 0.429699 & Prob. F $(13,9)$ & & 0.9190 \\
\hline \multicolumn{5}{|c|}{ Normality Test } \\
\hline Jarque-Bera & 2.084724 & Prob Value & & 0.352621 \\
\hline
\end{tabular}




\subsection{Results of the Granger Causality Test}

Table 4.6 shows that a unidirectional causality exists from population to unemployment. In other words, previous level of population can explain the present level of unemployment, and not the reverse. Similarly, a unidirectional causality also exists from the size of domestic market to unemployment and from FDI inflows to unemployment. Similarly, a unidirectional causality from FDI inflow and from domestic market size to population increase also exists. Unsurprisingly, domestic size is found to granger-cause FDI inflows, but unemployment is found to granger-cause exchange rate.

Table4.6: Granger Causality Tests

\begin{tabular}{|c|c|c|c|c|c|}
\hline & D(TOTUEM) & $\mathrm{D}(\mathrm{POPULOT})$ & D(FDIFLO) & D(DOMEMA) & D(EXCHAN) \\
\hline D(TOTUEM) & & $\begin{array}{r}3.667158 \\
(0.1598)\end{array}$ & $\begin{array}{c}3.606877 \\
(0.1647)\end{array}$ & $\begin{array}{l}0.351574 \\
(0.8388)\end{array}$ & $\begin{array}{l}15.90116^{* * *} \\
(0.0004)\end{array}$ \\
\hline D(POPULOT) & $\begin{array}{l}12.38038 * * * \\
(0.0020)\end{array}$ & & $\begin{array}{l}4.958586^{*} \\
(0.0838)\end{array}$ & $\begin{array}{l}2.551750 \\
(0.2792)\end{array}$ & $\begin{array}{l}5.160417 * \\
(0.0758)\end{array}$ \\
\hline $\mathrm{D}$ (FDIFLO) & $\begin{array}{c}15.10391 * * * \\
(0.0005)\end{array}$ & $\begin{array}{c}10.24637 * * * \\
(0.0060)\end{array}$ & & $\begin{array}{l}0.521196 \\
(0.7706)\end{array}$ & $\begin{array}{l}1.331920 \\
(0.5138)\end{array}$ \\
\hline D(DOMEMA) & $\begin{array}{l}6.054080 * * \\
(0.0485)\end{array}$ & $\begin{array}{l}6.332861^{* *} \\
(0.0422)\end{array}$ & $\begin{array}{l}7.679257 * * \\
(0.0215)\end{array}$ & & $\begin{array}{l}0.683828 \\
(0.7104)\end{array}$ \\
\hline $\mathrm{D}(\mathrm{EXCHAN})$ & $\begin{array}{l}0.748253 \\
(0.6879)\end{array}$ & $\begin{array}{l}2.869997 \\
(0.2381)\end{array}$ & $\begin{array}{l}2.664839 \\
(0.2638)\end{array}$ & $\begin{array}{l}0.503040 \\
(0.7776)\end{array}$ & \\
\hline
\end{tabular}

Probability values in () $* * *$ indicates significance at $1 \%, * *$ indicates significance at $5 \%$,

Sources: Author Computation, 2019.

\subsection{Conclusion and Recommendation \\ 5.1 Conclusion}

Empirical analysis was carried out in testing the impact of unemployment on economic growth in Nigeria, using the OLS multiple regression analytical method. Total unemployment rate (dependent variable) was regressed on total population in the country, size of domestic market or activities, flow of FDI, and exchange rate(independent variables) between 1991-2016. It was established in the study that population and exchange rate have positive effects on unemployment while domestic market and FDI both have negative effects on unemployment in Nigeria. Based on the findings of this study, it is concluded that unemployment has serious consequences on the Nigerian economy. Employment generation as seen in this study is a means of alleviating poverty, increasing the level of economic activities which brings about economic growth. The unemployment situation in Nigeria is on the increase and it has resulted in increased poverty among the citizens, increased social vices, under utilization of human capacity, social alienation and weak purchasing power among others. Although the Nigerian Government in previous times had set up different policies and programmes to combat this menace, but these programmes have not made much impact and the expected result could still not be achieved. This is due to lack of transparency, lack of commitment to the programme, inadequate funding and absence of enabling environment, corruption and economic mismanagement among other reasons. This has made the Country to witness an alarming increase in unemployment incidence rather than reducing it.

\subsection{Recommendations}

The Government should ensure there is job creation in the economy especially in the agricultural and manufacturing sectors. Private sectors employers should be given subsidies so as to encourage them to employ more people.

The government should set up policies in order to develop the rural areas for employment generation. This would reduce the burden on the urban centers and also creates jobs for the working population. Agriculture should be promoted by designing and implementing policies that makes it more attractive than it is today by a better organization of the sector in terms of both production and marketing.

The government should encourage entrepreneurship and fully incorporates citizens into such programmes. Public- Private Partnership (PPP) should also be encouraged since there are specific junctures where nongovernment actors could stage interventions in complementing government efforts in providing adequate education, employment and economic opportunities to the youths.

Human Capital investment should be encouraged. The government should target on increasing expenditure on education and health, using oil revenue to fund both infrastructure and recurrent spending, and making sure that the existing funds are spent more efficiently.

Government should pursue a programme of selective industrialization, that is, industries should be selected for promotion according to their potential impact on stimulation of demand for local materials and labour. 


\section{REFERENCES}

Ajekomobi A \& Ayanwale. A (2005). Evaluate Of Past Policy: Measures for Solving Unemployment Problems in Nigeria. Jeen Publishing Company.

Anthony I, (2013). Population and its impact on level of unemployment in Least Developed Countries: An Appraisal of the Nigerian Economy. European Social Science Research Journal, 1(4), 277-279.

Arrow, K. (1962), "Economic Welfare and the Allocation of Resources for Invention", available at: http://www.nber.org/chapters/c2144 (accessed 2 July 2017).

Aurangzeb, D. (2013). Factors Effecting Unemployment: A Cross Country. International Journal of Academic Research in Business and Social Sciences, 3(1), 219-230.

Baccaro, L. and Rei, D. (2007), "Institutional Determinants of Unemployment in OECD Countries: Does the Deregulatory View hold Water”, International Organization, Vol. 61 No. 3, pp. 527-569.

Barro, J. and Xaver J.M. (1995). Economic Growth. New York: MC Graw-Hill

Bello. (2003). Meeting the Challenge of Risking Unemployment in Employment, Policy \& Strategy Formulation Mission to Nigeria, Report Submitted by the IL. 21st Oct-22nd November.

Billetoft, J., Powell, M. and Treichel, V. (2008), "Nigeria: Labour Market Trends and Skills Development", Working Paper, World Bank, Washington D.C., 3 May.

Blanchard, O.J. and Wolfers, J. (2000), "The Role of Shocks and Institutions in the Rise of European Unemployment: The Aggregate Evidence”, Economic Journal, Vol.110 No. 462, pp. C1-C33. International Journal of Development and Sustainability Vol.6 No.7 (2017): 369-384 ISDS www.isdsnet.com 383

Boeri, T. and Macis, M. (2008), Do unemployment benefit, promote or hinder structural change,' Working Paper 3371, Institute of Labour Economics, Bonn Germany, 28 May.

Botero, J., Djankov, S., La Porta, R., Lopez de Silanes, F. and Shleifer, A. (2003), "The Regulation of Labour", Working Paper 9756, National Bureau of Economic Research, Cambridge, United Kingdom, 9 June.

Cingano, F., Marco, L., Julian, M. and Giovanni, P. (2010), "The Effects of Employment Protection Legislation and Financial Market Imperfections on Investment: Evidence from a Firm-Level Panel of EU Countries", Economic Policy, Vol. 25 No. 61, pp.117-163.

C.B.N/World Bank, (1994). Employment Policies and Poverty in Nigeria: Annual Report on Various Issues April. Central Bank of Nigeria: Statistical Bulletin (2004) National Population Commission (1991). Census News. Vol. 2 No. 1116-1196.

Fabio, R. and Scharler, J. (2011), "Labor Market Institutions and Macroeconomic Volatility in a Panel of OECD Countries", Scottish Journal of Political Economy, Vol. 58 No. 3, pp. 396- 413.

Eric, B. (1998). The Malthus Factor: Population, Poverty and Politics in Capitalist Development. London: Zed. Books.

Evans, L.T, (1998). Feeding the Ten Billion-Plant and Population Growth. Cambridge M.A.: University Press.

Gujarati. (1995). Growth \& Employment, in Development Problem Countries. New York, McGraw-Hill, Publishers.

Hirschman, A.C. (1958) The Strategy of Economic Development. New Haven: Yale University Press.

Johnson, B.G. and Lee, R.D. (1987). Population and Economic Development. USA: University of Wisconsin Press. Levin \& Wright (2000). Nigeria Unemployment Problem Tim Int. Journal, Sept, 19 Vol.1 No 1.

Lindbect. (1999).Unemployment In Developing Countries: An Over-View. New York: Mc Grow-Hill Publishers.

Nickel. (1999) Issues on Unemployment \& Violence, Second Edition. New York Grow-Hill. Note. Osinubi. (2006).The Political Crisis \& Solution Vanguard July 19

Petrin, A. and Sivadasan, J. (2006), "Job Security Does Affect Economic Efficiency Theory: A New Statistic and Evidence from Chile", Working Paper No. 12757, National Bureau of Economic Research, Cambridge, United Kingdom, 8 December.

Pigou, A.C. (1933), Theory of Unemployment, Macmillan, London.

Rebelo, S. (1991), "Long Run Policy Analysis and Long Run Growth”, Journal of Political Economy, Vol. 99 No. 3 , pp. 500-507.

Romer, P. (1986), “Increasing Returns and Long-Run Growth”, Journal of Political Economy, Vol. 94 No. 5, pp. 1002-1037.

Romer, P. (1987), "Growth Based on Increasing Returns Due to Specialization”, American Economic Review, Vol. 77 No. 2, pp. 56-62.

Romer, P. (1990), “Are Non convexities Important for Understanding Growth”, American Economic Review, Vol. 80 No. 2, pp. 97-103.

Romer, P. (1994), "New Goods, Old Theory, and the Welfare Costs of Trade Restrictions" Journal of Development Economics, Vol. 43 No. 1, pp. 5-38.

Schindler, M. (2009), "The Italian Labor Market: Recent Trends, Institutions, and Reform Options", Working Papers 09/47, International Monetary Fund, Washington D.C., 1 March.

Schlicht, E. (2011), "Wage Setting in Modern Labor Markets: Neither Fair nor Efficient”, Working Paper No. 26, 
Institute of Labour Economics, Bonn Germany, 4 April

Thirlwall, H.L. (1979), "Estimating the Determinants of the Unemployment Duration for College Graduates in Taiwan”, Applied Economics Letters, Vol. 6 No. 10, pp. 773-798.

Tvydon, M. (2015), "Labour Market Performance in EU Member States: A Panel Regression Approach", Journal of Economics, Business and Management, Vol. 3 No. 1, pp. 34-37.

Udabah, S.I, (2002). Economic Development Growth and planning Enugu State: Linc Press Nigeria Limited.

Uzawa, H. (1965), “Optimum Technical Change in an Aggressive Model of Economic Growth" International Economic Review, Vol. 6 No. 1, pp. 18-31. 